\title{
Education for Democratic Citizenship through A Literacy-based Approach: A Case of South African Township Children
}

\author{
Ina Joubert, Nkidi Phatudi and Melanie Moen \\ University of Pretoria, Pretoria Gauteng South Africa
}

Teresa Harris

James Madison University, Harrisonburg VA USA

The study contextualises the position of child citizens in the South African democracy and highlights how education for democratic citizenship is employed through a literacy-based approach. The qualitative study was exploratory and based on a lesson presented to nine-year-old township children by giving them language-related tasks. Through the children's voices we present the life experiences that expressed their need for basic services, education, extra facilities and security. We argue that children need to experience the benefits of democracy and education for democratic citizenship to build and sustain a resilient democratic society.

Keywords: democracy at risk, education for democratic citizenship, English First Additional Language, literacy-based approach, real-life experiences, township children.

\section{Introduction}

Despite the recent discourse about the intentions of democratic education (Abdi and Carr, 2013) there is widespread support for education for democratic citizenship to provide the foundation for sustainable democratic societies. However, in South Africa there seems to be no large-scale initiative to enhance education for democratic citizenship.

Democracy, even in nation states where it is long established, such as the USA, France and Britain, is a potentially fragile system (Starkey, 2005:24). Wilde (2005) argues that a democracy requires the commitment of all citizens to its ideals of creating a prosperous future for all. Waghid (2005) is of the opinion that values such as responsibility, accountability and tolerance will allow a democracy to flourish. According to Jamieson and others (2010/2011) participation is integral to these values and relates to the relationship between people and the state. As part of the shared membership in a community, adults and children need to work together for the good of the community (Jamieson and others, 2010/2011).

Democracy can only be achieved if citizens understand the characteristics of a democratic way of life and the consequences of its potential loss (Starkey, 2005). Education, specifically education for democratic citizenship, is decisive to a culture of democracy with the capacity to create personally responsible, participative and justice-orientated citizens; starting from the early grades (Westheimer and Kahne, 2004). Therefore, democratic governments are increasingly opting for specific school programmes to educate their child citizens (Ellis, 2010; Osler, 2005; Starkey, 2005).

In this article, we report on a qualitative study we conducted and share our insights on the possibility of extending education for democratic citizenship in the South African context. We investigated the role of the president in South African democracy, as viewed by 
nine-year-old children, through a literacy-based approach. We facilitated different language activities which the children completed. We refer to these activities as learning tasks. Through these learning tasks we discovered the children's life worlds, which helped us to answer our research question: How will the life experiences of nine-year-old township children affect education for democratic citizenship? In the next section, we discuss the relation between citizenship and democracy as well as child citizens and education for democratic citizenship. This approach enabled us to contextualise the position of child citizens in the South African democracy democratic dispensation and showed us how a literacy-based approach can be used to educate learners for democratic citizenship.

\section{Citizenship and democracy}

The notion of 'citizenship' is a disputed concept, as it relates to people in various ways (Osanloo, 2009). Osler (2005), for one, argues that it promotes a multi-layered perspective of citizenship that includes multiple identities of individuals. According to Osler (2005), citizenship can be understood as status, feeling and practice. The legal status of citizens is determined by the individual's relation to a particular nation state. Within a legal framework, this relationship determines the rights and obligations of that person. The rights generally associated with citizenship are those of living and working in a particular country and of voting. Additional rights are protection through laws and policing, collective benefits such as education, health care and infrastructure such as water supply and transport. The access to such services promotes the feeling of belonging to a democratic dispensation. In return, citizens contribute to the costs of collective benefits through taxation.

In South Africa, citizenship and its benefits are protected by the Constitution of the Republic of South Africa. However, at present some of these benefits, such as medical care and housing, are not always available, as they are in high demand by both citizens and noncitizens (Armstrong and others, 2008). In addition, there were only 5.9 million registered taxpayers in South Africa in 2011 and there are $~ 52$ million people living in South Africa (www.politicsweb.co.za). This implies that only 10 per cent of the population contributes to government funding as there is a constant influx of illegal immigrants to South Africa. This situation leads to an ongoing conflict between the civil, political and social rights of people that find themselves within the borders of South Africa (Eager, 2013), and there seems to be a scramble for resources, which are never sufficient for an ever growing population.

Citizenship as practice refers to both formal political activities such as voting and informal political activities such as campaigning activities. Predictors for participation are people's trust in social institutions and the belief that they can make a difference (Osler, 2005; Torney-Purta and others, 2004). However, participation requires a sense of belonging, and without this affective domain citizens are not interested in taking part in political activities (Holden and Clough, 2000). In the South African context, there are campaigns to promote participation in municipal and national elections. However, a survey conducted by the Institute for Justice and Reconciliation revealed that 40 per cent of young Black people and twothirds of other races have little or no faith in the county's political parties. Forty-nine per cent of the 3500 people who were interviewed during March and April 2012 doubted that national leaders were concerned with the views of ordinary people (www.reconciliationbarometer.org). One can argue that young South Africans are losing faith in the democratic institutions.

\section{Child citizens and education for democratic citizenship}

Young children are able to construct their own understandings of citizenship and a democratic identity in a democracy that offers them a constructive life world (Joubert and others, 
2010). However, children's position in society is complex. Empirical studies indicate that young children (9-12 years) are concerned about environmental destruction, crime, violence and social inequalities (Egan-Bitran, 2010). As a result they wish to be active in working towards effective change to ensure improved environmental and social conditions (Holden and Clough, 2000). The Convention on the Rights of the Child (United Nations General Assembly, 1989) gives children the right to seek information, to express their thoughts and feelings, to have them listened to and to take part in decisions affecting them. However, to fulfil the role of active and responsible citizens, South African children have to be educated in citizenship from a very early age (Ministry of Education, 2001:3).

Although children's position in the political context of democracies is ill defined, children are regarded as agents of change who require an educational system that will meet their needs and those of society. Starkey (2005) as well as Sunal and Haas (2011) are of the opinion that the vehicle for equipping children from a very young age to become informed citizens of a democratic dispensation is a literacy-based approach.

\section{Education for democratic citizenship}

\section{International perspectives}

There are many governments that are in consensus regarding what constitutes education for democratic citizenship and what its goals are (Chapin, 2006; Kerr, 2003; Starkey, 2005). According to Wilde (2005) citizenship is not only learning about it but also the practice of it.

Education for democratic citizenship has multiple purposes. It aims to enhance young children's knowledge about what civics is and why it is important. It also engages children in citizenship processes related to the actions and attitudes of civic responsibility and promotes critical thinking about civic dispositions and virtues (Maxim, 2010). These purposes align with those of the United Nations and its constituent bodies, such as the United Nations Educational, Scientific, and Cultural Organization (UNESCO) (2003), which promote the construction of a free, tolerant and peaceful world.

\section{National perspectives}

Values and human rights as stated by the Constitution form the foundation of the national curriculum. The national curriculum (Department of Basic Education, 2011a,b:4) is further based on principles such as 'social transformation, active and critical learning, human rights, inclusivity, environmental and social justice'. It aims to produce children that are able to identify and solve problems and make decisions using critical and creative thinking in becoming active and responsible citizens. Although the national curriculum promotes education for democratic citizenship it is not stated explicitly as such. Only aspects of education for democratic citizenship are included in the subject Life Skills (Department of Basic Education, 2011a,b). For a country whose democracy was already described in 2004 as fragile by Moodley and Adam (2004), as morally corrupt by Du Plessis (2013) in, and struggling to serve its people by Botman (2013) in, educators need to promote education for democratic citizenship.

\section{A literacy-based approach to education for democratic citizenship}

The role of language teaching in promoting democracy is acknowledged by governments worldwide (Maxim, 2010). Yet, it is still to be fully implemented. In addition, the links between the agenda for language teaching and the agenda for education for democratic citizenship need to be defined (Starkey, 2005). 
The language pertains especially to the position of English as a global lingua franca. As a lingua franca, it does not have the cultural enrichment of children as its main aim, but is considered as a language to learn about other cultures and enhance critical cultural awareness within the framework of human rights (Starkey, 2005). Internationally, there are many children with limited proficiency in English. However, through education for democratic citizenship their English can be strengthened as they learn and use vocabulary such as responsibility, vote and government (Chapin, 2006).

In South Africa, the level of language proficiency is a serious concern (Mudzielwana, 2012). One of the contributing factors to this dilemma is that for many South African children English is their second or third language. Alongside their home language they are taught English in Grades 1-3 because from Grade 4 they then have to learn all subjects in English. Many children are not ready to learn in English. However, through education for democratic citizenship they can develop essential skills that include word recognition (including phonics skills), vocabulary and comprehension of texts and speech. These language skills assist them to respond to a wide variety of situations related to the democratic dispensation, for instance addressing problems on classroom and school level and answering questions critically (Joubert and others, 2013).

We argue that the pedagogy associated with language teaching and learning provides the platform for deliberation about all aspects of citizenship in a democracy. In addition, as stated by Schell and Fisher (2007), it provides a space where young children can express their experiences about real-life issues such as living with the challenges in their communities, particularly in a township. Through language they will be able to develop citizenship skills such as conceptualising key concepts associated with democracy and identifying cause and effect (Schell and Fisher, 2007). They can also voice their opinions about local, national and international issues relevant to them and share their ideals and dreams about a future life in a democratic society. This is especially true when teaching young children in the Foundation Phase, where an integrated approach to knowledge and language is followed (Moss, 2005).

\section{Theoretical framework}

Various theories apply to education for democratic citizenship (Alexander, 2002) but only a few are related to the South African context (Vally, 2005; Waghid, 2010). Resulting from the absence of rigour concerning this research focus, especially on education for democratic citizenship through literacy, we employed the Turning Points Literacy Teaching Model (Centre for Collaborative Education, 2011) for this research project. This model promotes education for democratic citizenship through language teaching and learning.

The designers of the model argue that if schools are places where children become highly literate, they must also be places where children are encouraged to become active and responsible citizens. Literacy is seen as a social act that supports the process of thinking, questioning, problem probing and problem-solving. When regarding literacy as a social activity, teachers need to take into account the different backgrounds and experiences of children about the democratic dispensation and employ these when choosing content for literacy teaching. The Turning Points Literacy Teaching Model emphasizes the engagement of children in their own learning.

The model is framed by five interconnected practices, which together form the pillars of literacy teaching that is embedded in democracy and equity. Practice one focuses on critical literacy through the language skills of speaking and acting as well as reading and writing. Critical literacy skills enable children to participate actively in debate about democratic practices such as the equal distribution of services (e.g. community libraries). Practice two refers to the teaching of literacy through explicit instruction. Practice three enhances the idea of 
teaching literacy by giving students authentic, meaningful work to do. Practice four focuses on the important aspect of continuous assessment, as assessment is an integral part of teaching and learning. Practice five elaborates the support of a coherent, school-wide approach. Engaging children in becoming literate requires classroom and school structures that support the general aim of teaching, which is, in this instance, to assist children to be critical about their democratic citizenship and participate responsibly in democratic processes at classroom and school level.

Besides the above theory, we accepted additional theories which strengthened our theoretical framework. The theory of authentic learning, as described by Slabbert and others (2009), is understood as the facilitation of meaningful real-life encounters where children become active in their own learning. Through such learning experiences children are transformed from 'learning to know', and 'learning to do' to 'learning to be'. Thus, education becomes an experience of life itself. The theory of building a learning community promotes learning processes that are democratic and focused on real-life problem-solving (MacNaughton and Williams, 2004). To guide our research project, we constructed a conceptual and theoretical framework as presented in Figure 1.

\section{Methodological considerations}

\section{Sampling and data generation}

The unit of analysis was one Grade 3 class at a previously called disadvantaged primary school. The school was purposively chosen as it is part of a larger research project related to the enhancement of the literacy skills of both teachers and children in the Foundation Phase. The school is a governmental township school, situated on the outskirts of the Tshwane metropolis in the Gauteng province of South Africa. In South Africa, a township is what used to be a Black settlement during the apartheid era and consists mostly of formal brick

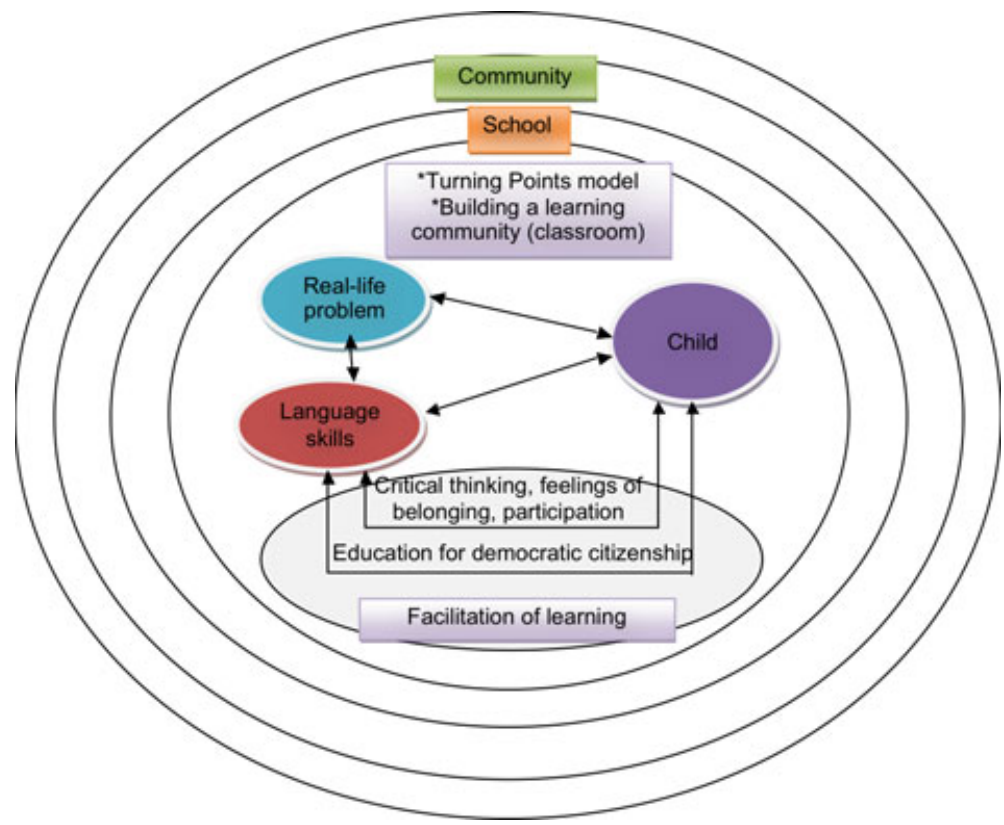

Figure 1. Conceptual and theoretical framework. 
housing and informal houses such as shacks (houses constructed of materials such as steel sheets and construction discards). It is a large primary school with 350 children and nine teachers in Grades 1-3. The class consists of 43 children, a teacher and no teaching assistant. Although the language of learning and teaching is Setswana, children speak various African languages such as Xitshonga and TshiVenda. English is consequently the children's additional language.

Our strategy was to facilitate a lesson regarding the role of the president of South Africa to create data through the different learning tasks presented to the children. Other data were collected by observations, field notes, semi-structured interviews with the class teacher and the principal who visited the class during the lesson, and photographs that captured the learning atmosphere in the classroom. The topic related to the recent municipal elections as the posters of the municipal elections were still visible on lamp posts. We argued that the children would be aware of what was going on in their real-life worlds. We used concepts related to education for democratic citizenship, such as the rights and responsibilities of child citizens and voting as an act of responsible participation. We employed facilitation of learning (Slabbert and others, 2009) to create a learning environment that is inviting and where children could construct their own understanding.

We used learning tasks based on imaginative role play such as the completion of the sentence: If I were president I would ..., the creation of slogans for a poster starting with: Vote for me because .... and the making of a mind map on The roles of the president. We explained the various learning tasks by means of prompts and questions to facilitate creative thinking (Slabbert and others, 2009), for example: 'Do you know what the role of the president of our country is? If you want people to vote for you, what will you write on the poster to use during election time?' The intention was to grasp the children's interest by giving them diverse learning tasks (Joubert and others, 2013:26-28). The lesson cycle of the extended lesson included different stages that included media such as photographs of present and past presidents of South Africa. In each of the stages, the children's cognitive and language skills were engaged (refer to Table 1 for a summary of the lesson stages, the teaching activities, the learning tasks and the format of the group work; Photos 1 and 2).

Working with young children can be a challenging undertaking (Punch, 2002:328; Viviers, 2010), especially when dealing with their life experiences. Therefore, we ensured that this

Table 1: Summary of lessons

\begin{tabular}{|c|c|c|c|}
\hline Stage & Teaching activities & Learning tasks & $\begin{array}{l}\text { Children's } \\
\text { engagement }\end{array}$ \\
\hline One: Initiate learning & $\begin{array}{l}\text { Facilitation, questions and prompts, } \\
\text { involvement of whole class. }\end{array}$ & & \\
\hline \multirow[t]{3}{*}{ Two: Maintain learning } & $\begin{array}{l}\text { Facilitation, explanation of tasks, } \\
\text { whole class, children execute } \\
\text { learning tasks }\end{array}$ & $\begin{array}{l}\text { Task one: Completing } \\
\text { the sentence: If I } \\
\text { were president I would... }\end{array}$ & Individual \\
\hline & & $\begin{array}{l}\text { Task two: Slogans on } \\
\text { poster starting } \\
\text { with: Vote for me because... }\end{array}$ & Group \\
\hline & & $\begin{array}{l}\text { Task three: Mind map on The } \\
\text { roles of the president }\end{array}$ & Group \\
\hline $\begin{array}{l}\text { Three: Learning } \\
\text { task feedback }\end{array}$ & $\begin{array}{l}\text { Facilitation, children come to front } \\
\text { of class, tell about and show } \\
\text { their contributions }\end{array}$ & $\begin{array}{l}\text { Randomly selected } \\
\text { individuals and groups }\end{array}$ & \\
\hline $\begin{array}{l}\text { Four: Learning task } \\
\text { consolidation }\end{array}$ & $\begin{array}{l}\text { Facilitation, summary of } \\
\text { contributions, whole class }\end{array}$ & & \\
\hline
\end{tabular}




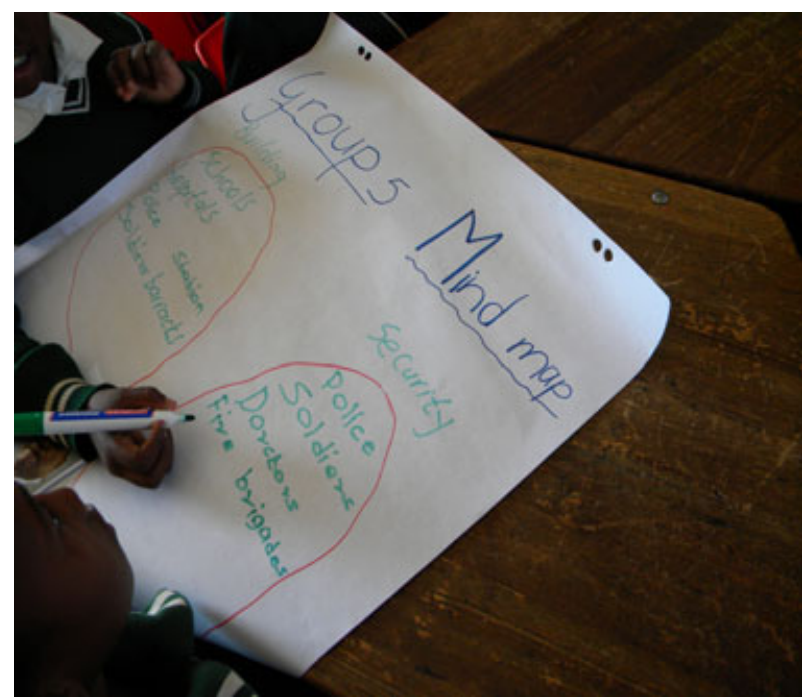

Photo 1. Stage three of the lesson: designing a mind map.

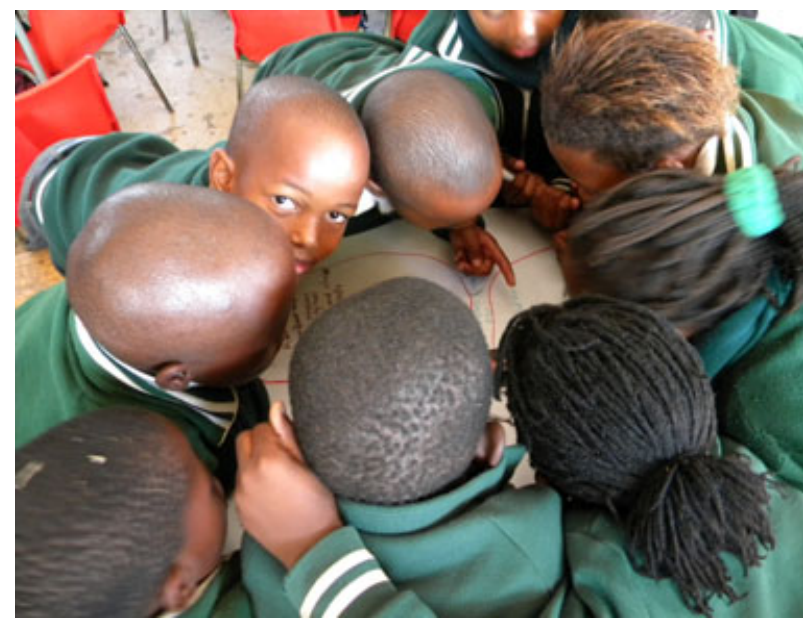

Photo 2. Enthusiastic participation.

research project was conducted in a negotiated, ethical manner (Denzin and Lincoln, 2000). Written consent was obtained from the school authorities, the parents and the children.

\section{Data analysis and results}

Through a deductive process we analysed the children's comments on the democratic dispensation on the one level and the children's language skills on another level.

\section{Democratic dispensation}

We employed the constructivist grounded theory analysis method to analyse the data created by the children through the learning tasks (Charmaz, 2000). This methodology assisted us to construct meaning from the textual data in an attempt to understand the children's comments about the democratic dispensation as they experienced it in their particular context. 
Through an inductive analysis of each set of textual data and across all data we identified emerging themes. In the Discussion section we present the four themes which emerged, namely voice, education, extra facilities and security.

\section{Language skills}

The language skills of listening, speaking and reading in EFAL (English First Additional Language) were integrated throughout the lesson, especially in the cooperative groups. The language skills of writing and using EFAL language structure were analysed by studying the various textual data. During the lesson and learning tasks we observed the children's ability to do the following:

- act in imaginative role play,

- listen to our explanations and instructions,

- listen to each other,

- answer our questions and to talk to each other in the groups, and

- read their own contributions.

The children were able to articulate their ideas when speaking, but had difficulty expressing themselves in writing and spelt words incorrectly. Examples of words that were mostly spelled incorrectly were because (becose), people (pipoles) and build (bueld, bulild). In many cases, the home language merged with English. We noted that the children who worked in groups made fewer spelling mistakes because they assisted each other. In the groups, they were also more engaged in completing the learning tasks than the ones who were writing the sentences on their own.

\section{Discussion}

In terms of the democratic dispensation, the data across the different learning tasks indicated that the young participants have a voice regarding their life experiences. The children were knowledgeable about the challenges, basic needs and the need for extra facilities in their own community. One child wrote: 'If I were president I would build houses'. In addition, they were informed about the trends in the broader context of South Africa such as the need for more school buildings. There is evidence that children's voices are not often heard in research projects concerning the political or civic affairs of a nation (Holden and Clough, 2000). One reason for this might be the adult's perception that participation in decisionmaking is a threat to their own rights.

Through the study we discovered that the children were concerned about their education; 92 per cent $(24 / 26)$ of the participants who completed the written-sentence exercise expressed their need for schools. One child wrote: 'If I were president I would build schools'. Both groups wrote slogans about the need for schools. One group wrote the slogan: 'Vote for me I will build schools'. Two groups wrote the word 'schools' under the caption 'Buildings' on their mind maps. Although the school was situated in a previously disadvantaged area, the school was functioning well. These responses triggered the following question: Why are they so concerned about building new schools? It appears to be contradictory information, because the government does have a plan to develop and build new schools. However, often the dire situations of communities where children have to attend vandalised schools and schools made of mud are shown on television. Children also wrote about teachers who needed payment, and one child mentioned that strikers also need payment. We argue that children could have been influenced by the television images, especially the footage of striking teachers belonging to certain unions. It is reported that teacher strikes consume as much as 10 school days a year, or 5 per cent of school time (www.ai.org.za). 
The necessity of extra facilities emerged as the following theme. Extra facilities were associated with the need for houses, money in the form of social grants and services such as hospitals, doctors, electricity, toilets, food, clothing and clean water. When looking at the overwhelming data on this theme, it can be interpreted as a cry for the provision of basic needs. Many children indicated that they needed Reconstruction and Development Program (RDP) houses (the government's RDP focuses on alleviating poverty and addressing shortfalls in social services across South Africa). In the township there are many informal houses among the brick houses. Both groups wrote slogans about the provision of houses. One group wrote the slogan: 'Vote for me I will make sure that you have houses'. Another group indicated on their mind map under the caption 'Development' that they needed 'houses'. In South Africa an estimated 17 million people live below the poverty line. One-fifth of the population lives in state-subsidised homes and 18.9 per cent of South African households live in RDP dwellings (www.anc.org.za). Most provinces' housing programmes are affected by limited funding, corruption, illegal bidding processes and substandard building materials.

Children also reported on the absence of recreational facilities in their communities, the dismal picture of unemployment and the problematic transport system, which included the dreadful state of roads. Much has been written on the subject of unemployment, transport and infrastructure. In South Africa, the unemployment rate rose to 25.2 per cent in the first quarter of 2013. It is estimated that 13.6 million South Africans are unemployed (www.southafrica.info). According to a survey done by the University of Johannesburg with 1000 participants, 61 per cent of the respondents rated transport as a high priority. Rural inhabitants in this study indicated that transport was the second highest priority after education (www.uj.ac.za).

The children's concerns regarding the lack of security in the context of this article are alarming and we identified this as theme four. This township is known for its criminal activities, but no statistics were available to indicate the status thereof. Children asked for protection on different levels, varying from protection of themselves, teachers, schools, the community, people and the nation. One child wrote: 'If I were President I would protect a schools' (sic). Another child wrote: 'If I were the President I would protect the nation' (sic). The same child also wrote that if he were president he would 'protect people from criminals'. Many of the children who completed the sentence stated that more police stations were needed and that police and soldiers needed to be paid. Three out of the five slogans were focused on security. South Africa is ranked fifth in the world when comparing total crimes committed in the world (www.nationmaster.com).

Citizenship emerged as a weak theme as only a few children referred to rights and responsibilities as well as participation. Although there were not nearly as many comments about citizenship as about the other themes, we noted them since the focus of the lesson was on citizenship. When completing the mind map learning task one group had a category with the caption 'rules (law)' and underneath it wrote 'rights and responsibilities', 'Child have the right to a nationality' (sic), and 'Everybody have rights to clean water'. In the context of education for democratic citizenship, the expressions of the children indicated limited knowledge of rights and responsibilities. One would expect that in a developing democracy these young children would be knowledgeable about their rights, as they are enshrined in the South African Constitution (Republic of South Africa, 1996). In a study done by the University of the Western Cape on citizenship, many of the eight- to nine-year-old group displayed misperceptions on the subject of 'rights'. They mostly associated rights with safety, protection and care. The children in this study also displayed considerable difficulty in distinguishing between rights and responsibilities (www.childwatch.uio.no). When interviewing the class 
teacher, it was evident that he had never thought of dealing with these concepts. This aspect still needs further investigation and research.

Only one of the 43 children expressed the idea of participation in a democratic government. One child wrote: 'If I were the President I will give government to the people' (sic). The fact that only one child commented on this aspect indicates the lack of knowledge about democratic government processes such as municipal elections but the potential to be educated about democratic participation. Joubert (2010) found in her study that nine-year-old South African citizens not only expressed their wish to participate in democratic processes but also expressed the absence of such opportunities.

The employment of aspects of citizenship education through the different stages of the lesson and the various teaching activities brought vigour to the classroom. Although they could not recall the municipal election (posters were still on lamp posts), the children were cooperating enthusiastically in completing their learning tasks assigned to them. When reporting back to the class they were noticeably proud of their end results.

The interviews with the class teacher as well as the principal revealed their appreciation for strengthening education for democratic citizenship. The class teacher admitted that he has never considered employing children's real-life experiences of a political nature in his teaching. In addition, they both recognised the advantages of a school-wide approach to education for democratic citizenship.

As little research is documented on education for democratic citizenship in the South African context, the critical literacy perspective as promoted by the Turning Points Literacy Model (Centre for Collaborative Education, 2011) guided us to enrich the participation, especially in the groups. The facilitation of a positive learning environment (Slabbert and others, 2009) contributed to the children's understanding of the role of the president. The creation of this environment provided us with the major findings, namely that the expressions of the children's life experiences and understandings of the democratic dispensation can assist teachers in extending conceptions and practices of democratic citizenship education for the South African context. Our findings align with Waghid's (2010) notion that democratic citizenship education ought to be deliberative, compassionate and friendly in order that teachers and learners may respect one another and take risks in and through their pedagogical encounters.

\section{Conclusion}

Language learning can be an inviting experience for children and can be achieved by facilitating education for democratic citizenship. It can provide the vehicle for transmitting the core and shared values that are essential for sustaining democracy. However, this can only happen under the following conditions:

- young children's voices need to be taken seriously

- service delivery needs to be improved drastically, as it is evident that basic needs and facilities must be met before education for democratic citizenship can succeed

- a contextualised education for democratic citizenship needs to be developed with children's life experiences imbedded in it

- In South Africa, robust campaigning for education for democratic citizenship and the practice thereof need to be prioritised by all concerned.

With this research we posit that the children in this study revealed the capacity to be educated as democratic citizens and that their life experiences can inform the choice for the content of such education. 


\section{References}

http://www.anc.org.za; http://www.anc.org.za [Accessed 8 May 2013]. www.southafrica.info; http://southafrica.info/business/economy/employment [Accessed 8 May 2013]. www.nationmaster.com.

http://www.nationmaster.com/graph/cri_tot_qi_crime-total-crimes [Accessed 15 May 2013].

Abdi AA, Carr PR. 2013. Educating for Democratic Consciousness. Counter-hegemonic Possibilities. Peter Lang: Bern.

Alexander T. 2002. Citizenship Schools. A Practical Guide to Education for Citizenship and Personal Development. Southgate Publishers: Devon.

Armstrong P, Lekezwa B, Siebrits K. 2008. Poverty in South Africa: A profile based on recent household surveys. Stellenbosch Economic Working Papers: 04/08. University of Stellenbosch (Department of Economics \&t Bureau for Economic Research): Stellenbosch. Available at http://www.ekon.sun.ac. za/wpapers/2008/wp042008/wp-042008.pdf [Accessed 1 October 2012].

Botman R. 2013. Ons stuur jeug na fanatiese groepe. Free translation: we are guiding our youth to radicalism. Beeld 25 April 21.

Centre for Collaborative Education. 2011. Turning points. Transforming middle schools. Teaching literacy in the turning points school. Available at www.turningpts.org [Accessed 26 February 2013].

Chapin JR. 2006. Elementary Social Studies, 6th edn. Pearson: Boston.

Charmaz K. 2000. Grounded theory: objectivist methods. In Handbook of Qualitative Research, 2nd edn. Denzin NK Lincoln YS (eds.). Sage: London; 507-535.

Citizenship Research Network by the University of Western Cape, South Africa. 2004: Draft project report to Childwatch International. Children's perspectives on their rights, responsibility and citizenship. Available at www.childwatch.uio.no; http://www.childwatch.uio.no/research [Accessed 8 May 2013].

Denzin NK, Lincoln YS (eds.). 2000. Handbook of Qualitative Research, 2nd edn. Sage: Thousand Oaks, CA.

Department of Basic Education. 2011a. National Curriculum Statement (NCS). Curriculum and Assessment Policy Statement. Life Skills Foundation Phase Grades R-3. State Printer: Pretoria.

Department of Basic Education. 2011b. National Curriculum Statement (NCS). Curriculum and Assessment Policy Statement. English First Additional Language. Foundation Phase Grades R-3. State Printer: Pretoria.

Du Plessis T. 2013. Irriteer die lot net waar jy kan. Free translation: irritate the government whenever you can. Beeld 26 April, 16.

Eager D. 2013. Take care over the next hill. Mail \& Guardian 19 to 25 April 3.

Egan-Bitran M. 2010. 'This is How I See It.' Children, Young People and Young Adults' Views and Experiences of Poverty. Office of the Children's Commissioner: New Zeeland.

Ellis AK. 2010. The Teaching and Learning Elementary Social Studies, 5th edn. Pearson: Boston.

Holden C, Clough N. 2000. 'The child carried on the back does not know the length of the road': the teacher's role in assisting participation. In Children as Citizens. Education for Participation (Children in Charge Series 5). Holden C, Clough N (eds.). Jesssica Kingsley Publishers: London; 13-28.

Jamieson L, Pendlebury S, Bray R. 2010/2011. Conclusion: Children as Citizens. Part 2. South African Child Gauge: University of Cape Town; 70-73.

Joubert I. 2010. South Africa is My Best World. The Voices of Child Citizens in a Democratic South Africa. Peter Lang: Bern.

Joubert I, Ebersöhn L, Eloff I. 2010. How post-apartheid children express their identity as citizens. Childhood: A Global Journal of Child Research 17(3): 396-410. DOI: 10.117/0907568210369321.

Joubert I, Bester M, Meyer E, Evans R. 2013. Literacy in the Foundation Phase, 2nd edn. Van Schaik: Pretoria.

Kerr D. 2003. Citizenship in England: the making of a new subject. Online Journal of Social Sciences Education. Available at http://www.sowionlinejournal.de/2003-2/england_kerr.htm [Accessed 13 March 2006]. 
MacNaughton G, Williams G. 2004. Teaching Young Children. Choices in Theory and Practices. Open University Press: Berkshire.

Maxim GW. 2010. Dynamic Social Studies for Constructivist Classrooms. Inspiring Tomorrow's Social Scientists, 9th edn. Pearson: Boston.

Ministry of Education. 2001. Manifesto on Values, Education and Democracy. Wilmot J (ed.). Cape Argus Teaching Fund for the Department of Education: Cape Town.

Moodley KA, Adam H. 2004. Citizenship Education and Political literacy in South Africa. In Diversity and Citizenship Education. Global Perspectives. Banks JA (ed.). John Wiley \& Sons: San Francisco; 159-183.

Moss B. 2005. Making a case and place for effective content area literacy instruction in the elementary grades. The Reading Teacher, International reading association 59(1): 46-55.

Modisaotsile M.D. 2012. The failing standard of Basic Education in South Africa. Policy Brief. Africa institute of South Africa. No. 72 March 2012. Available at www.ai.org.za; http://www.ai.org.za/uncategorised [Accessed 8 May 2013].

Mudzielwana N. 2012. Teaching reading comprehension to Grade 3 Tshivenda-speaking childs. Unpublished PhD. University of Pretoria: Pretoria.

Osanloo AF. 2009. Civic responsibility and human rights education: a pan-educational alliance for social justice. Intercultural Education 20(2): 151-159. DOI: 10.14675980902922176.

Osler A. 2005. Education for democratic citizenship: new challenges in a globalized world. In Citizenship and Language Learning: International Perspectives. Osler A, Starkey H (eds.). Trentham in Partnership with the British Council: Stoke-on-Trent; 3-22.

Punch S. 2002. Research with children. The same or different from research with adults? Childhood 9 (3): 321-341. DOI: 10.1177/0907568202009003005.

Republic of South Africa. 1996. The Constitution of the Republic of South Africa. Act No. 108 of 1996. Government Gazette, 378(17678) - 18 December 1996. Government Printer: Cape Town.

Schell E, Fisher D. 2007. Teaching Social Studies. A Literacy-based Approach. Pearson: New Jersey.

Slabbert JA, De Kok DM, Hatting A. 2009. The Brave 'New' World of Education. Creating a Unique Professionalism. Juta: Cape Town.

Starkey H. 2005. Language teaching for democratic citizenship. In Citizenship and Language Learning: International Perspectives. Osler A, Starkey H (eds.). Trentham in partnership with the British Council: Stoke-on-Trent; 23-40.

Sunal CS, Haas ME. 2011. Social Studies for the Elementary and Middle Grades. A Constructivist Approach. Pearson: Boston.

Torney-Purta J, Richardson WK, Barber CH. 2004. Adolescents' trust and civic participation in the United States: Analysis of data from the IEA Civic Education Study. Fact sheet. The Center for Information \&t Research on Civic Learning \&t Engagement. Available at http://www.civicyouth.org/PopUps/ Factsheets/SF_Trust_CivicPart.pdf [Accessed 8 October 2012].

United Nations Educational, Scientific, and Cultural Organization (UNESCO). 2003. Learning to Live Together: Have We Failed? A summary of the ideas and contributions arising from the forty-sixth session of UNESCO's international conference on education. Geneva, 58 September 2001. International Bureau of Education: Geneva.

United Nations General Assembly, 1989. Convention on the Rights of the Child. Articles 12 and 13, 20 November 1989. United Nations, Treaty Series, 1577:3. Available at http://www.unhcr.org/refworld/ docid/3ae6b38fo.html [Accessed 8 October 2012].

Vally S. 2005. Citizenship and children's education rights in South Africa. Journal of Education 35: 31-47.

Viviers A. 2010. The Ethics of Child Participation. MEd dissertation. University of Pretoria: Pretoria.

Waghid Y. 2005. Action as an educational virtue: toward a different understanding of democratic citizenship education. Educational Theory 55(3): 322-342.

Waghid Y. 2010. Education, Democracy and Citizenship Revisited. Pedagogical Encounters. Sun Press: Stellenbosch.

Wale K. 2013. SA Reconcillation Bacometer Survey: report Available at http://www.reconciliationbarometer.org.2012.http:www.criminalbarometer.org/2013/4/reconciliation [Accessed 7 May 2013]. 
Westheimer J, Kahne J. 2004. What kind of Citizen? The politics of educating for democracy. American Educational Research Journal 41(2): 237-269. doi:10.3102/00028312041002237.

Wilde S (ed.). 2005. Political and Citizenship Education: International Perspectives. Symposium Books: Oxford. Available at http://www.politicsweb.co.za; http://www.politicsweb/view/politics [Accessed 7 May 2013].

*Correspondence to: Ina Joubert, University of Pretoria, Pretoria, Gauteng, South Africa, Tel.: +27 124205636; Fax: +27 124205595. E-mail: Ina.joubert@up.ac.za 